Submitted for publication in

Catalysis Communications (2009)

\title{
Deep oxidation of methane on particles derived from YSZ-supported Pd-Pt-(O) coatings synthesized by pulsed filtered cathodic arc.
}

\author{
D. Horwat ${ }^{\mathrm{a}, \mathrm{b}^{*}}$, J.L. Endrino ${ }^{\mathrm{b}, \mathrm{c}}$, A. Boreave ${ }^{\mathrm{d}}$, R. Karoum ${ }^{\mathrm{d}}$, J.F. Pierson ${ }^{\mathrm{a}}$, S. Weber ${ }^{\mathrm{e}}$, A. \\ Anders ${ }^{\mathrm{b}}$, Ph. Vernoux ${ }^{\mathrm{d}}$. \\ a Institut Jean Lamour, Département CP2S, Ecole des Mines, CS14234 Parc de Saurupt, F- \\ 54042, Nancy cedex, France \\ b Plasma Applications Group, Lawrence Berkeley National Laboratory, 1 Cyclotron Road, \\ Berkeley, CA 94720, USA \\ c Instituto de Ciencias de Materiales de Madrid, Consejo Superior de Investigaciones Cientificas, \\ Campus de Cantoblanco, E-28049 Madrid, Spain \\ d Université Lyon 1, CNRS, UMR 5256, IRCELYON, Institut de recherches sur la catalyse et \\ l'environnement de Lyon, 2 avenue Albert Einstein, F-69626 Villeurbanne, France \\ e Institut Jean Lamour, CC-MEM, Ecole des Mines, CS14234 Parc de Saurupt, F-54042 Nancy \\ cedex, France
}

* Corresponding author. Tel.: +33 383584252.

E-mail address: david.horwat@mines.inpl-nancy.fr.

The work at Berkeley Lab was supported by the U.S. Department of Energy under Contract No. DE-AC02-05CH11231.

This document was prepared as an account of work sponsored in part by the United States Government. While this document is believed to contain correct information, neither the United States Government nor any agency thereof, nor The Regents of the University of California, nor any of their employees, makes any warranty, express or implied, or assumes any legal responsibility for the accuracy, completeness, or usefulness of any information, apparatus, product, or process disclosed, or represents that its use would not infringe privately owned rights. Reference herein to any specific commercial product, process, or service by its trade name, trademark, manufacturer, or otherwise, does not necessarily constitute or imply its endorsement, recommendation, or favoring by the United States Government or any agency thereof, or The Regents of the University of California. The views and opinions of authors expressed herein do not necessarily state or reflect those of the United States Government or any agency thereof or The Regents of the University of California. 
Deep oxidation of methane on particles derived from 2 YSZ-supported Pd-Pt-(O) coatings synthesized by 3 pulsed filtered cathodic arc.

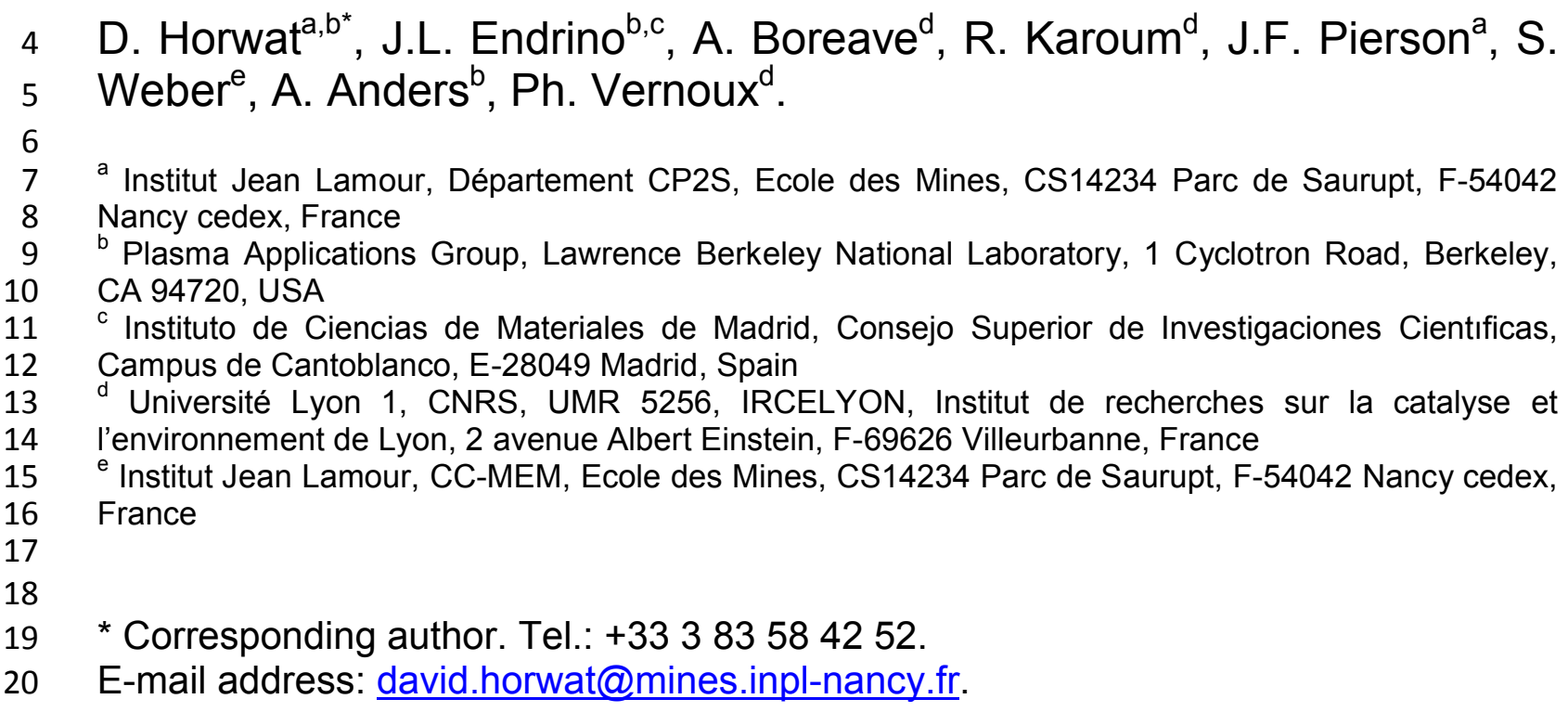

${ }^{a}$ Institut Jean Lamour, Département CP2S, Ecole des Mines, CS14234 Parc de Saurupt, F-54042 Nancy cedex, France

${ }^{\mathrm{b}}$ Plasma Applications Group, Lawrence Berkeley National Laboratory, 1 Cyclotron Road, Berkeley, CA 94720, USA

${ }^{c}$ Instituto de Ciencias de Materiales de Madrid, Consejo Superior de Investigaciones Cientificas, Campus de Cantoblanco, E-28049 Madrid, Spain

d Université Lyon 1, CNRS, UMR 5256, IRCELYON, Institut de recherches sur la catalyse et l'environnement de Lyon, 2 avenue Albert Einstein, F-69626 Villeurbanne, France

${ }^{\mathrm{e}}$ Institut Jean Lamour, CC-MEM, Ecole des Mines, CS14234 Parc de Saurupt, F-54042 Nancy cedex, France

* Corresponding author. Tel.: +33 383584252.

E-mail address: david.horwat@mines.inpl-nancy.fr.

\section{Abstract}

\section{Introduction}


a challenge for the reduction of working temperature of $\mathrm{CH}_{4}$ combustion turbines.

Palladium catalysts have been shown to belong to the most effective catalysts for methane combustion (e.g. [1-6]) and to be more active than other transition metals for this reaction $[5,7,8]$. While bulk $\mathrm{PdO}$ is claimed to be inactive, a thin layer of $\mathrm{PdO}$ on metallic $\mathrm{Pd}$ is proposed to be the active form of palladium [8-10]. It was suggested that $\mathrm{CH}_{4}$ combustion occurs via the Mars-van Krevelen mechanism where $\mathrm{O}_{2}$ is assumed to oxidize the palladium surface, the formed surface oxide being reduced by $\mathrm{CH}_{4}$ [4]. A bifunctional mechanism for methane oxidation over $\mathrm{Pd} / \mathrm{ZrO}_{2}$ catalysts has already been suggested, where metallic Pd particles dissociatively chemisorb methane producing adsorbed $\mathrm{H}$ and $\mathrm{CH}_{\mathrm{X}}$ species $[8,10]$. Reoxidation rapidly converts the metal back to the oxide. The predominance of either metallic palladium-supported $\mathrm{PdO}$ or a $\mathrm{Pd} / \mathrm{PdO}_{\mathrm{y}}$ mixture for active oxidation of methane is still highly controversial. For $\mathrm{Al}_{2} \mathrm{O}_{3}$ support, the incorporation of $\mathrm{Pt}$ in $\mathrm{Pd}$ has been reported to improve and stabilize the catalytic oxidation of methane via Pd-Pt interaction (e.g. [12, 13]). On the contrary, Persson et al. observed superior conversion efficiency for $\mathrm{Pd}$ than $\mathrm{Pd}-\mathrm{Pt}$ equimolar mixture, the latter presenting higher long term stability [14].

Pulsed Filtered Cathodic Vacuum Arc (PFCVA) can be successfully employed to deposit various chemical systems such as diamond like carbon (DLC), metal doped DLC $[15,16]$ and metal oxide $[17,18]$ films. The high reactivity of the evaporated species associated with the technique and the use of a dual cathode deposition system (DC-PFCVA) is expected to lead to the successful synthesis of binary and ternary noble metal oxide films. In the present study, yttria stabilized zirconia (YSZ) supported Pd-based catalysts were considered due to the applicability of YSZ 
supports to solid oxide fuel cells and car engine exhausts where electrochemical 60 promotion of catalysis start being considered $[19,20]$. This study presents DCPFCVA as a suitable technique to synthesize various metallic or oxide thin films for catalytic reactions, and explores the thermal evolution of the catalytic activity for YSZsupported metallic $\mathrm{Pd}, \mathrm{Pd}$ oxides and $\mathrm{Pd}_{\mathrm{X}} \mathrm{Pt}_{1-\mathrm{x}}$ oxides.

\section{Experimental}

\subsection{Sample preparation}

Metallic $\mathrm{Pd}, \mathrm{Pd}$ oxide and $\mathrm{Pd}_{\mathrm{X}} \mathrm{Pt}_{1-\mathrm{x}}$ oxide films were prepared on $\mathrm{YSZ}$ pellets (14 $\mathrm{mm}$ in diameter, $1 \mathrm{~mm}$ thick). The system contains a dual-cathode "triggerless" minigun [21], which was designed to operate in pulsed mode. The two cathodes incorporated in the source were pure palladium and platinum. The pulsed operation of these cathodes was controlled using a custom National Instruments' LabView ${ }^{\mathrm{TM}}$ software. Once the computer has sent a signal to the arc power supply, an arc discharge pulse on a selected cathode is triggered simply by application of a high open circuit voltage (of about $600 \mathrm{~V}$ ). The pulsed arc current employed was about 700 A with a pulse duration of about $1 \mathrm{~ms}$. A pulse repetition rate of four pulses per second was employed for all films. The two mixed $\mathrm{Pd}_{1-\mathrm{X}} \mathrm{Pt}_{\mathrm{X}} \mathrm{O}_{Y}$ films were deposited by alternating one platinum pulse and one palladium pulse for the higher Ptcontaining $\mathrm{Pd}_{1-\mathrm{X}} \mathrm{Pt}_{\mathrm{X}} \mathrm{O}_{Y}$ film, and one platinum pulse for every two palladium pulses for the lower Pt-containing $\mathrm{Pd}_{1-X} \mathrm{Pt}_{\mathrm{X}} \mathrm{O}_{Y}$ film. The plasma stream produced by the mini arc source was injected into a 90-degree filter to remove most of the macroparticles, which were formed during the cathodic arc evaporation process [22]. After exiting the 
90-degree filter, the plasma stream travelled through a magnetic multipole homogenizer with $16.7 \mathrm{~cm}$ inner diameter in order to improve the film uniformity [22]. The substrate holder was grounded and rotated at a rate of 2 revolutions per minute during the deposition. The distance between the exit of the filter to the homogenizer was about $3 \mathrm{~cm}$, and the distance from the magnetic homogenizer to the substrate was about $2 \mathrm{~cm}$. The vacuum base pressure was typically in the $10^{-4} \mathrm{~Pa}$ range, the process pressure was set at approximately $2.13 \mathrm{~Pa}(16 \mathrm{mTorr})$. For the deposition of the pure palladium film, pure Ar was used as process gas while for the deposition of the oxide films pure oxygen was introduced to the chamber at 16 standard cubic centimeters per minute. The films were deposited at the same time on cubic YSZ pellets and silicon wafer pieces.

\subsection{Sample characterization}

The structural characteristics of the films were probed by grazing incidence $X$-ray diffraction (GIXRD) at an incident angle of $2^{\circ}$ with respect to the substrate surface. The experiments were done with a Co-Ka source (wavelength of $0.178897 \mathrm{~nm}$ ) using an INEL diffractometer. The film composition was measured by secondary neutral mass spectrometry (SNMS) with an $8 \mathrm{keV} \mathrm{Ar}^{+}$primary beam. The apparatus is a SimsLab-VG. The typical currents on the samples were in the range 300-500 nA and the sputtered atoms were post-ionised by the electrons emitted from a filament for the mass spectrometry analysis. The quantification procedure of the relative $\mathrm{Pd}$ and Pt content and the estimate of the oxygen content of as-grown films included, first, a calibration of the SNMS measurements using thick crystalline $\mathrm{Pt}_{2} \mathrm{O}$ and $\mathrm{PdO}$ sputtered reference films, as well as SNMS measurements of a thick $\mathrm{Pd}_{0.85} \mathrm{Pt}_{0.15} \mathrm{O}_{\mathrm{y}}$ 
107 film whose metals stoichiometry was previously determined by energy dispersive 108 spectroscopy (EDS). The compositions of thin catalyst films where then deduced 109 from the integration of the SNMS profile corrected using the calibration. The surface 110 of the Pd-based catalysts was observed by scanning electron microscopy (SEM, 111 XL30S FEG Philips). Thickness measurements were carried out with a Dektak IIA 112 profilometer on films deposited on flat silicon substrates.

113 Catalytic measurements were performed at atmospheric pressure in a specific quartz reactor described in a previous study [23, 24]. The catalysts were placed on sintered quartz, $18 \mathrm{~mm}$ in diameter. The reactive mixture passed through the porous disk from below and then licked the catalyst surface. A K-type thermocouple was located close to the catalytic surface. The reaction gases were mixtures of $\mathrm{CH}_{4}$ (Air Liquide, $5 \% \mathrm{CH}_{4}$ in $\mathrm{He}$ ) and $\mathrm{O}_{2}$ (Air Liquide $5 \% \mathrm{O}_{2}$ in $\mathrm{He}$ ). The gas composition was controlled by mass flow controllers (Brooks, with accuracies better than 1\%). In the following, the gas composition will be expressed in ppm or \%. The reactive mixture (RM) is containing $\mathrm{CH}_{4} / \mathrm{O}_{2}: 5100 \mathrm{ppm} / 4 \%$. The overall gas flow rate was kept with $\mathrm{He}$ constant at $72 \mathrm{~mL} \mathrm{~min}^{-1}\left(+/-2 \mathrm{~mL} \mathrm{~min}^{-1}\right)$. To study the catalytic performance and the thermal ageing, three cycles were performed between $250^{\circ} \mathrm{C}$ and $800^{\circ} \mathrm{C}$ at a ramp of $10^{\circ} \mathrm{C} \mathrm{min}^{-1}$ with a plateau of two hours at $800^{\circ} \mathrm{C}$ for each sample. The comparisons between catalytic surfaces of $\mathrm{Pd}, \mathrm{PdO}$, and $\mathrm{Pd}_{x} \mathrm{Pt}_{1-\mathrm{x}} \mathrm{O}_{\mathrm{y}}$ were performed during cycling. The reactants and products were analysed by an IPC400TM INFICON 127 quadrupole mass spectrometer. Signals at $\mathrm{m} / \mathrm{e}=15,18,28,32,44 \mathrm{amu}$ 128 corresponding to $\mathrm{CH}_{3}{ }^{+}, \mathrm{H}_{2} \mathrm{O}^{+}, \mathrm{N}_{2}{ }^{+}$or $\mathrm{CO}^{+}, \mathrm{O}_{2}{ }^{+}$and $\mathrm{CO}_{2}{ }^{+}$ions, respectively, were 129 recorded. The conversion of methane was defined as the percentage of methane 
130 feed converted into $\mathrm{CO}_{2}$. Carbon dioxide was the only oxidation product detected.

\section{Results and discussions}

Some characteristics concerning catalytic coatings are reported in Table. 1. The as-deposited Pd films were found to be nanocrystalline with an average grain size of about $10 \mathrm{~nm}$ while all the oxide films were amorphous. SEM examination of the samples revealed a complete coverage of the YSZ surface by the deposited materials with a dense morphology. While palladium oxide, $\mathrm{PdO}$, and platinum dioxide, $\mathrm{PtO}_{2}$, are stable in air at low temperatures, they start reducing in air at around $750^{\circ} \mathrm{C}$ [7] and $450^{\circ} \mathrm{C}$ [25], respectively. The estimated oxygen content in the as-deposited films $(y)$ decreases with the incorporation of Pt. The methane conversion curves of the deposited films upon heating after a first RT- $800^{\circ} \mathrm{C}-\mathrm{RT}$ (RT: room temperature) thermal cycle are displayed on Fig. $1 \mathrm{a}$. The $\mathrm{Pd}, \mathrm{PdO}_{\mathrm{y}}$ coatings promote methane deep oxidation upon heating below $770^{\circ} \mathrm{C}$ whereas the promotion by the $\mathrm{Pd}_{0.6} \mathrm{Pt}_{0.4} \mathrm{O}_{\mathrm{y}}$ film stops at roughly $750^{\circ} \mathrm{C}$. The highest conversions occurred for as-deposited $\mathrm{Pd}$ and $\mathrm{PdO}_{y}$ films. Very low catalytic activity is observed on $\mathrm{Pd}_{0.4} \mathrm{Pt}_{0.6} \mathrm{O}_{y}$ film. The present results are in accordance with the detrimental effect of Pt incorporation into $\mathrm{Pd}_{1-x} \mathrm{Pt}_{\mathrm{x}}$ for $x \geq 0.33$ reported by Persson et al. for the same reaction [14].

For a better comparison of the different catalysts, the reaction rate has been calculated in reference to the palladium loading (Fig.1 b). The representation highlights a superior catalytic activity of as-deposited palladium oxide films compared 
154 to metallic palladium. The behavior of $\mathrm{Pd}_{0.6} \mathrm{Pt}_{0.4} \mathrm{O}_{\mathrm{y}}$ is characterized by lower activity between $580^{\circ} \mathrm{C}$ and $680^{\circ} \mathrm{C}$. This might be related to the onset of the reduction of oxidized platinum. In this context, it is worth noting that Seriani et al. calculated a higher efficiency of platinum oxide $\left(\mathrm{Pt}_{3} \mathrm{O}_{4}\right)$ than $\mathrm{Pt}$ for $\mathrm{CH}_{4}$ cracking [26]. We believe that the strong platinum reducibility explains the improved reducibility of the compound, leading to a reaction rate drop at $680^{\circ} \mathrm{C}$ for $\mathrm{Pd}_{0.6} \mathrm{Pt}_{0.4} \mathrm{O}_{y}$ and of the negligible activity for $\mathrm{Pd}_{0.4} \mathrm{Pt}_{0.6} \mathrm{O}_{\mathrm{y}}$.

The thermal cycling behavior of the as-deposited $\mathrm{Pd}$ and $\mathrm{PdO}_{\mathrm{y}}$ films is shown in Fig. 2. Starting from metallic palladium, the onset of the catalytic conversion is observed at $550^{\circ} \mathrm{C}$ upon the first heat up, whereas $\mathrm{PdO}_{y}$ is already active at $400^{\circ} \mathrm{C}$. The reaction rate drops at $735^{\circ} \mathrm{C}$ and $725^{\circ} \mathrm{C}$ for initially $\mathrm{Pd}$ and $\mathrm{PdO}_{\mathrm{y}}$ films, respectively. These temperatures cause the reduction of $\mathrm{PdO}$ into metallic $\mathrm{Pd}$. They are higher than the $700^{\circ} \mathrm{C}$ reported in oxidizing mixtures by Furuya et al. for $\mathrm{Pd}$ nanoparticles on YSZ [27], and the $715^{\circ} \mathrm{C}$ reported by Roche et al. for 52-nm thick Pd thin films sputter-deposited on YSZ [28]. Cooling down the samples from $800^{\circ} \mathrm{C}$, surface re-oxidation occurs, thereby restarting the conversion the hydrocarbons. However, the reoxidation of the surface occurs at a lower temperature than the reduction upon heating. Both materials exhibit an activity hysteresis of about $100^{\circ} \mathrm{C}$. The phenomenon is qualitatively consistent with the original observation by Farrauto et al. for $\mathrm{Al}_{2} \mathrm{O}_{3}$-supported $\mathrm{Pd}$ [7]. The thermal cycling of $\mathrm{PdO}_{\mathrm{y}}$ did not give any evidence for strong differences between the cycles. In the case of Pd, the first heating is associated to a lower activity. This indicates a strong structural or/and chemical evolution of the $\mathrm{Pd}$ film during the first heating. From the previous discussion, the reducibility of the compounds drives the thermal evolution of the catalytic activity. Palladium was the only crystalline as-deposited film. The GIXRD 
179 signature of the different samples after the third cycle is represented on Fig.3. These

investigations interestingly highlight that the final structural state is very sensitive to the initial composition:

- The only phase detected for Pt-containing films is metallic (no Pt oxide).

- The as-deposited Pd film transformed into a biphased alloy consisting of Pd and $\mathrm{PdO}$.

- The as-deposited $\mathrm{PdO}_{y}$ film converted into crystalline PdO. The reddish colour characteristic of PdO could be observed only for that sample.

Therefore, the hypothesis of the higher reducibility of Pt-containing films is confirmed. The SEM observation of both initially $\mathrm{Pd}$ and $\mathrm{PdO}_{y}$ films shows an important evolution of the morphology towards clusters of particles dispersed at the surface of the zirconia substrate (Fig. 4). $\mathrm{PdO}_{y}$ evolved in jagged clusters of few particles with a characteristic size of the particles close to $100 \mathrm{~nm}$. The clusters derived from the Pd film are bigger and more spherical in shape. Significant coalescence occurred between the particles. The differences in shapes and sizes are linked to strong differences in the surface to volume ratio. Using a spherical approximation for the particle shape, the dispersion of the catalyst was estimated to 6 and $16 \%$ for initially $\mathrm{Pd}$ and $\mathrm{PdO}_{\mathrm{y}}$ films respectively. Assuming a surface oxidation for both compounds within the thermal domain of active heterogeneous catalysis, the latter parameter obviously explains the discrepancy between the maximal activities of the two compounds.

\section{Conclusions}


Methane conversion tests were performed on $\mathrm{Pd}, \mathrm{PdO}_{\mathrm{y}}, \mathrm{Pd}_{0.6} \mathrm{Pt}_{0.4} \mathrm{O}_{\mathrm{y}}$ and

$\mathrm{Pd}_{0.4} \mathrm{Pt}_{0.6} \mathrm{O}_{\mathrm{y}}$ thin films deposited by Dual Cathode Filtered Cathodic Vacuum Arc on YSZ substrates. The catalytic activity curves over thermal cycling were discussed in terms of the reducibility of the deposited compounds. The film with the highest $\mathrm{Pt}$ content exhibited poor activity and $\mathrm{Pd}_{0.6} \mathrm{Pt}_{0.4} \mathrm{O}_{\mathrm{y}}$ showed limited activity and high reducibility. In contrast, during the cycling process, the as-deposited $\mathrm{Pd}$ and $\mathrm{PdO}_{\mathrm{y}}$ films showed good activity despite the transformation to clusters of particles dispersed on the YSZ substrates. The higher reaction rate of the initially $\mathrm{PdO}_{\mathrm{y}}$ films was explained by a better dispersion of the catalyst. The drop in the reaction rate, associated with the reduction of $\mathrm{PdO}$ into $\mathrm{Pd}$ at high temperature, was measured at $735^{\circ} \mathrm{C}$ and $725^{\circ} \mathrm{C}$ for the initially $\mathrm{Pd}$ and $\mathrm{PdO}_{\mathrm{y}}$ films, respectively. After three thermal cycles up to $800^{\circ} \mathrm{C}$, it was not possible to detect either $\mathrm{Pd}$ or $\mathrm{Pt}$ oxides in the $\mathrm{Pt}$ containing films. As-deposited $\mathrm{Pd}$ evolved to a $\mathrm{Pd} / \mathrm{PdO}$ mixtures, only crystalline $\mathrm{PdO}$ was detected for initially $\mathrm{PdO}_{\mathrm{y}}$ amorphous films.

\section{Acknowledgments}

220 Work at Berkeley Lab was supported by the U.S. Department of Energy under 221 Contract No. DE-AC02-05CH11231. 
References

[1] F. H. Ribeiro, M. Chow and R. A. DallaBetta, J. Catal. 146 (1994) 537.

[2] C.A.Müller, M. Maciejewski, R. A. Koeppel, R. Tschan and A. Baiker, J. Phys. Chem. 100 (1996) 20006.

[3] K. Fujimoto, F. H. Ribeiro, M. Avalos-Borja and E. Iglesia, J. Catal. 179 (1998) 431.

[4] R. A. DallaBeta and T. Rostrup-Nielsen, Catal. Today 47 (1999) 369.

[5] G. Centi, J. Mol. Catal. A 173 (2001) 287.

[6] P. Gelin and M. Primet, Appl. Catal. B 39 (2002) 1

[7] R. J. Farrauto, M. C. Hobson, T. Kennelly and E. M. Waterman, Appl. Catal. A 81 (1992) 227

[8] J.N. Carstens, S.C. Su and A.T. Bell, J. Catal. 176 (1998) 136

[9] R. Burch and F. J. Urbano, Appl. Catal. A 124 (1995) 121

[10] S.C. Su, J.N. Carstens and A. T. Bell, J. Catal. 176 (1998) 125

[11] S. Yang, A. Maroto-Valientea, M. Benito-Gonzaleza, I. Rodriguez-Ramosa and A. Guerrero-Ruiz, Appl. Catal. B 28 (2000) 223

[12] G. Lapisardi, L. Urfels, P. Gelin, M. Primet, A. Kaddouri, E. Garbowski, S. Toppi, E. Tena, Catal. Today 117 (2006) 564

[13] H. Yamamoto, H. Uchida, Catal. Today 45 (1998) 147

[14] K. Persson, A. Erssona, K. Janssonb, N. Iverlund, S. Järås, J.Catal. 231 (2005) 139

[15] J.L. Endrino, R. Escobar Galindo, H.-S. Zhang, M. Allen, R. Gago, A. Espinosa, A. Anders, Surf. Coat. Technol. 202 (2008) 3675

[16] J.L. Endrino, D. Horwat, R. Gago, J. Andersson, Y.S. Liu, J. Guo, A. Anders, Sol. Stat. Sci, In Press, corrected proofs, DOI: 10.1016/j.solidstatesciences.2008.08.007

[17] S. Anders, A. Anders, M. Rubin, Z. Wang, S. Raoux, F. Kong, I.G. Brown, Surf. Coat. Technol. 76-77 (1995) 167

[18] R.A. MacGill, S. Anders, A. Anders, R.A. Castro, M. R. Dickinson, K.M. Yu, I.G. Brown, Surf. Coat. Technol. 78 (1996) 168

[19] C.G. Vayenas, S. Bebelis, C. Pliangos, S. Brosda, D. Tsiplakides (2001) Electrochemical Activation of Catalysis: Promotion, Electrochemical Promotion MetalSupport Interactions. Kluwer Academic/Plenum, New York

[20] X. Li, F. Gaillard, P. Vernoux, Topics in Catalysis 44 (2007) 391 
257 [21] A. Anders, N. Pasaja, and S. Sansongsiri, Rev. Sci. Instrum., 78 (2007) 063901

2258 [22] A. Anders, Cathodic Arcs: From Fractal Spots to Energetic Condensation. New 3259 York: Springer, 2008

260 [23] P. Vernoux, F. Gaillard, L. Bultel, E. Siebert, M. Primet, J. Catal. 208 (2002) 412

261 [24] F. Gaillard, X. Li, M. Uray, P. Vernoux, Catal. Letters 96 (2004)177

262 [25] K.L. Saenger, C. Cabral Jr. C. Lavoie, S.M. Rossnagel, J. Appl. Phys. 86 (1999) 2636084

264 [26] N. Seriani, W. Pompe, L. Colombi Ciacchi, J. Phys. Chem. B (2006) 14860

265 [27] T. Furuya, K. Sasaki, Y. Hanakata, T. Ohhashi, M. Yamada, T. Tsuchiya, Y. 266 Furuse, Catal. Today 26 (1995) 345

267 [28] V. Roche, R. Karoum, A. Billard, R. Revel, P. Vernoux, J. Appl. Electrochem. 38 $268 \quad$ (2008) 1111 


\section{Figure captions}

Figure 1: Methane conversion a), methane reaction rate in reference to the $\mathrm{Pd}$ load b) over the deposited compounds during the second heat up from $250^{\circ} \mathrm{C}$ to $800^{\circ} \mathrm{C}$.

Figure 4: $\mathrm{PdO}$ particles derived from thermally cycled $\mathrm{PdO}_{\mathrm{y}}$ films deposited films a), mixed $\mathrm{PdO}+\mathrm{Pd}$ particle clusters derived from thermally cycled $\mathrm{Pd}$ films deposited films b).

Figure 2: Evolution of the methane reaction rate during thermal cycling.

Figure 3: X-ray diffraction patterns of the deposited compounds after thermal cycling. 


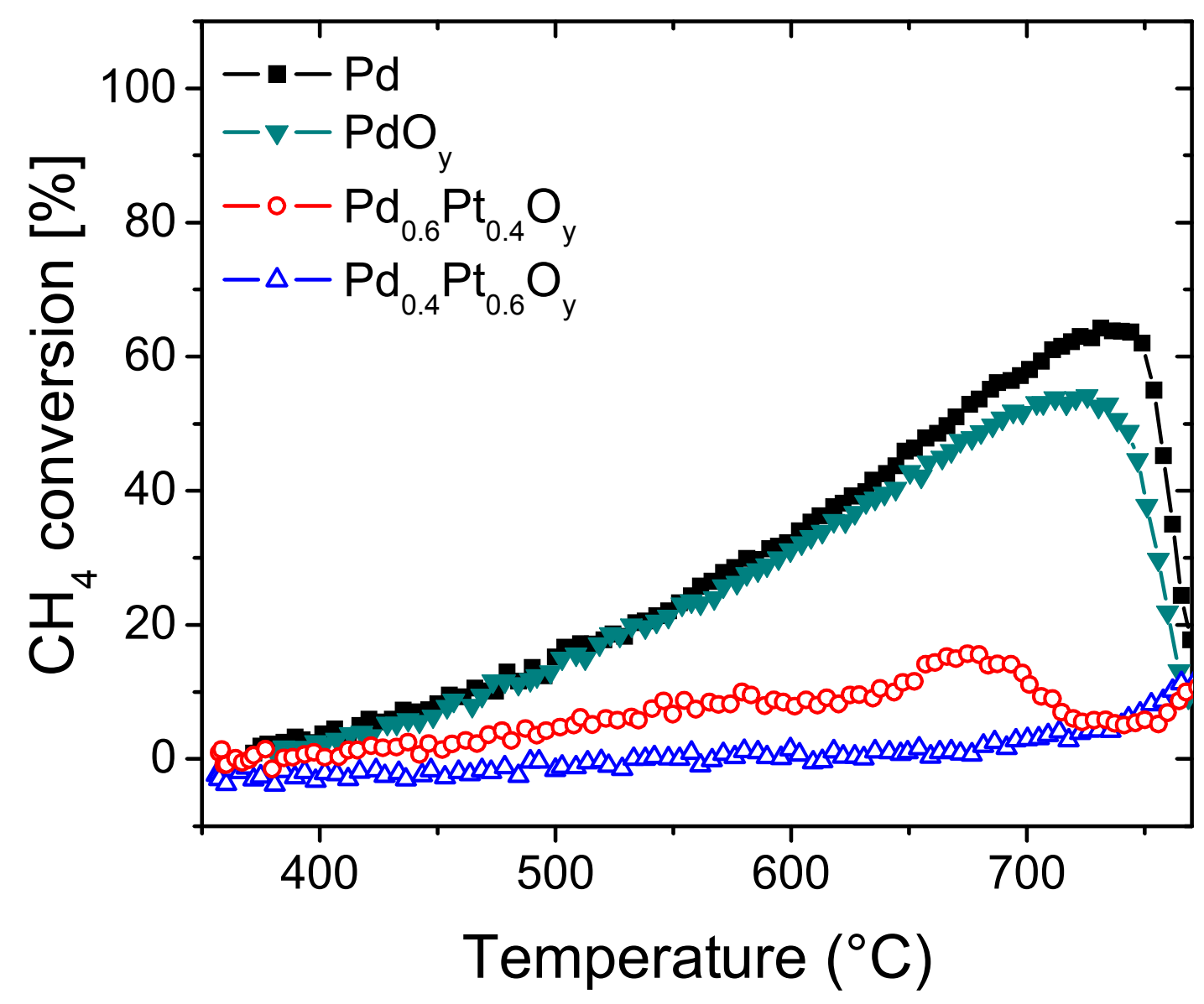




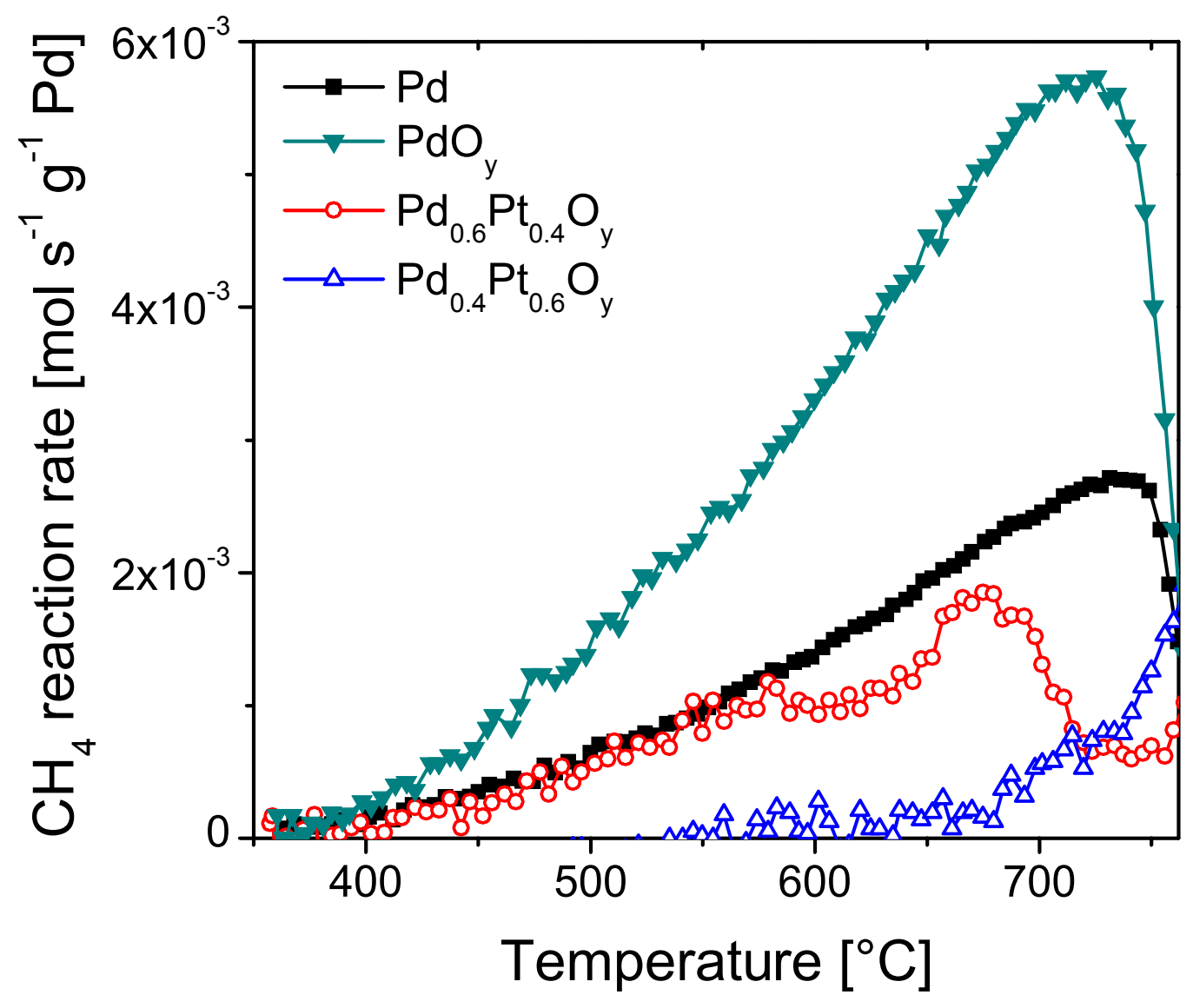




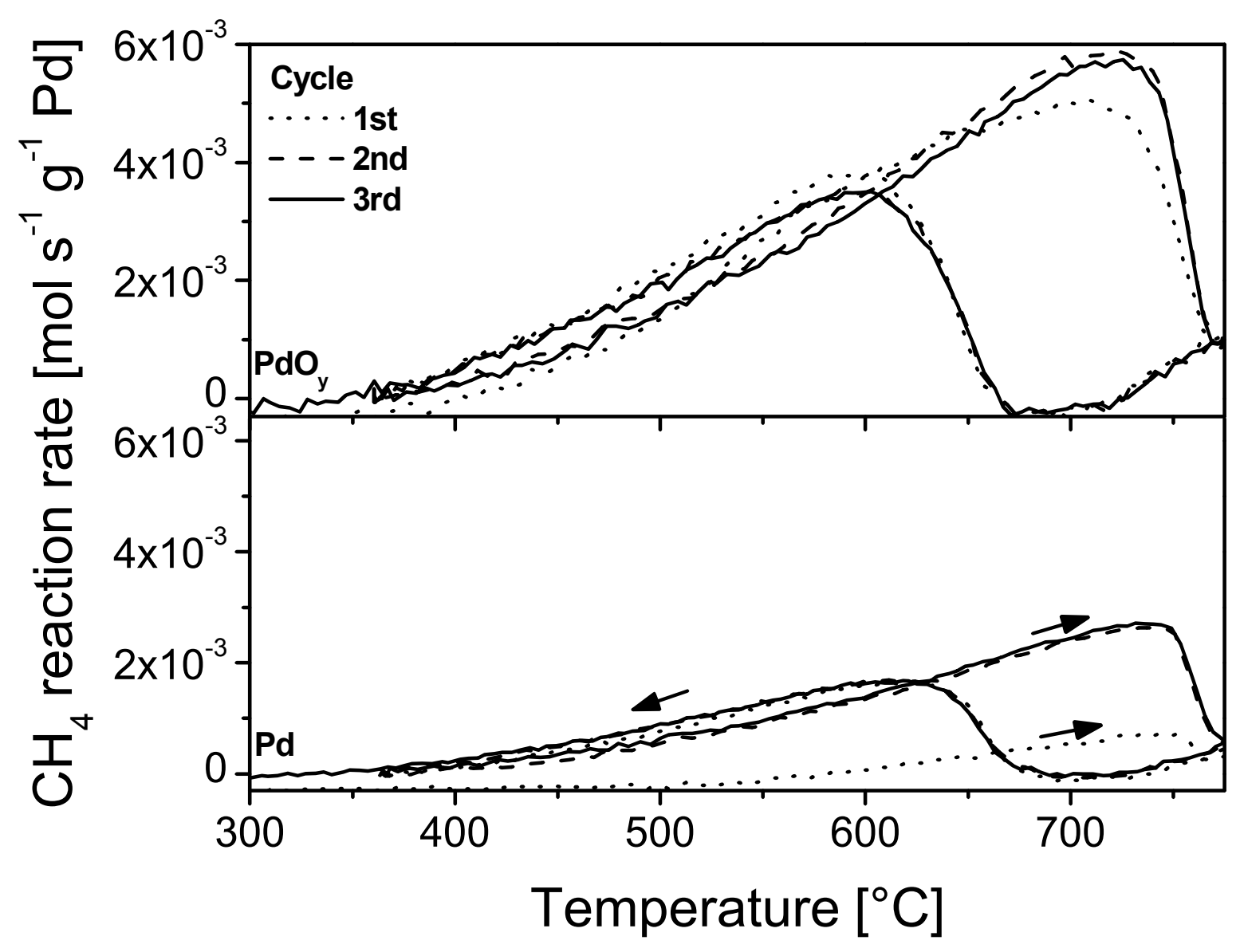




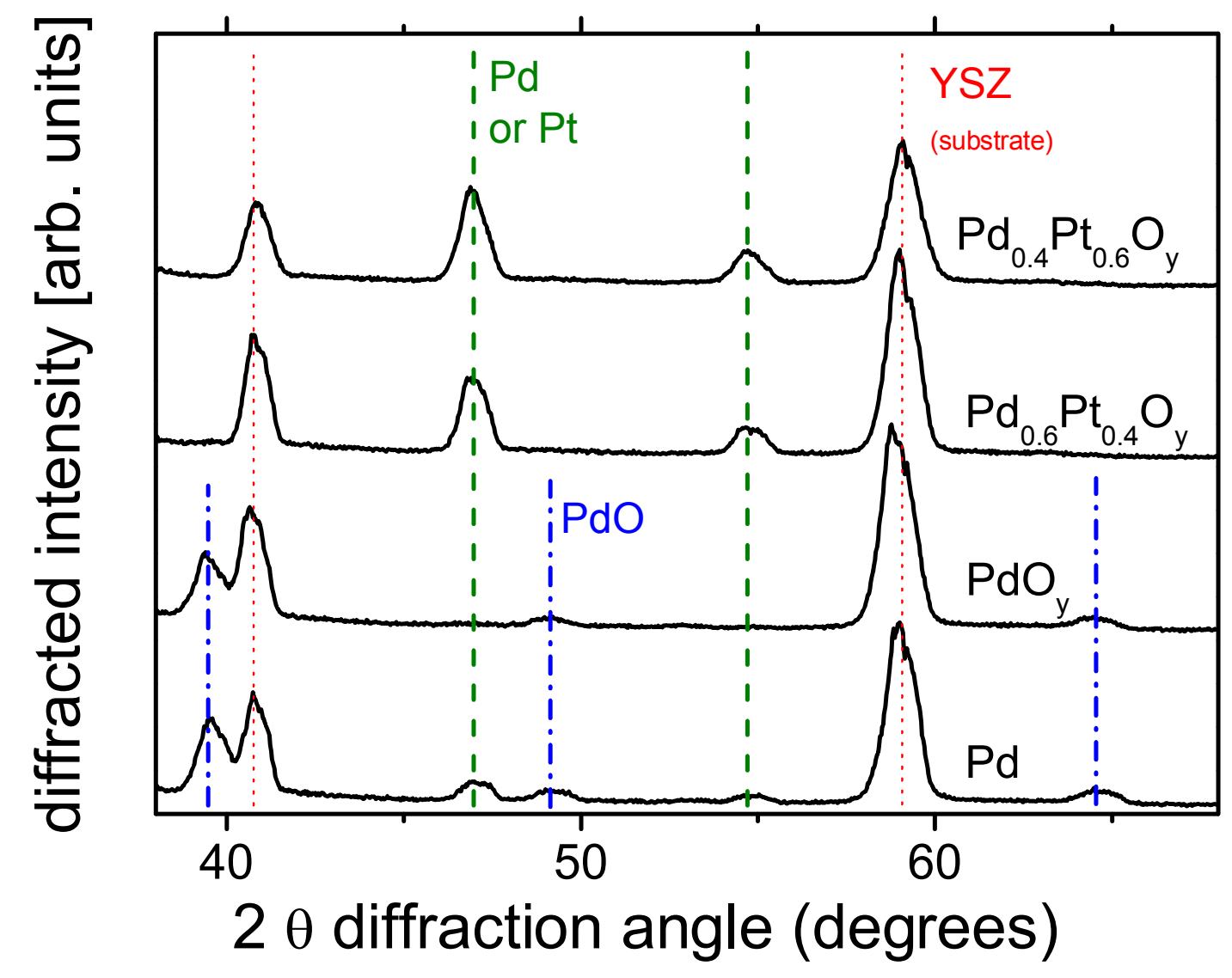




\begin{tabular}{|c|c|c|c|c|c|c|}
\hline Composition & Initial structure & $\begin{array}{l}\text { Thickness } \\
\text { (nm) }\end{array}$ & $\begin{array}{l}\text { Oxygen/Metal } \\
(y) *\end{array}$ & $\begin{array}{l}\text { Pd loading } \\
(\mu \mathrm{g})\end{array}$ & $\begin{array}{c}\text { Final structure } \\
\text { (3 cycles) }\end{array}$ & $\begin{array}{l}\text { Maximal catalytic rate } \\
\left(\mathbf{m m o l ~} \mathrm{CH}_{4} \mathrm{~s}^{-1} \mathrm{~g}^{-1} \mathrm{Pd}\right)\end{array}$ \\
\hline Pd & nano-crystalline $(\sim 10 \mathrm{~nm})$ & 45 & I & 83 & $\mathbf{P d}+\mathbf{P d O}$ & 2.57 \\
\hline $\mathbf{P d O}_{\mathrm{y}}$ & amorphous & 34 & 0.96 & 40 & PdO & 5.9 \\
\hline $\mathbf{P d}_{0.6} \mathbf{P t}_{0.4} \mathrm{O}_{\mathrm{y}}$ & amorphous & 37 & 0.74 & 36 & Metal & 1.85 \\
\hline $\mathbf{P d}_{0.4} \mathbf{P t}_{0.6} \mathbf{O}_{\mathrm{y}}$ & amorphous & 35 & 0.63 & 23 & Metal & 1 \\
\hline
\end{tabular}

$\mathbf{P d}_{0.4} \mathbf{P t}_{0.6} \mathbf{O}_{\mathbf{y}}$ amorphous 